\title{
23. BIOGENIC SEDIMENTARY STRUCTURES (TRACE FOSSILS) IN LEG 15 CORES
}

\author{
John E. Warme, Department of Geology, Rice University, Houston, Texas \\ W. James Kennedy, Oxford University, Department of Geology and Mineralogy, Parks Road, Oxford OX1 3PR, England \\ and \\ Nahum Schneidermann ${ }^{1}$, Department of Geology, University of Illinois, Urbana, Illinois
}

\section{INTRODUCTION}

Sediment cores from the deep sea rarely show biogenic sedimentary structures so well preserved, in such variety, and so readily comparable with land-based occurrences as those in Deep Sea Drilling Project Leg 15 cores from the Caribbean Sea. These markings, or "trace fossils," were formed by sediment-dwelling benthonic animals that structured the sediment into distinctive patterns. Most trace fossils exhibited in the cores are records of the feeding behavior of marine invertebrates that exploited the sediment for food.

The well-indurated Upper Cretaceous sediments from Sites 146,152 and 153 best show the suite of traces. The majority of our examples are from Site 146, which was continuously cored and offers the greatest number and variety of specimens. In the overlying relatively unconsolidated Cenozoic sediments, the activity of benthonic animals is usually expressed as indistinct mottles or homogeneous beds. It is likely that the degree of induration of the Cretaceous rocks served to accentuate and better reveal the trace fossils described herein.

Our purposes are to document the trace fossils in the Caribbean cores, to compare them with traces described elsewhere, and to discuss the implications of these occurrences for paleogeographical and paleoecological studies.

We thank DSDP personnel for the opportunity to study the cores and for numerous courtesies, and C. Kent Chamberlain for thoughtful review of the manuscript.

\section{BENTHONIC LIFE AND DEEP SEA STRATIGRAPHY}

Most cores from the deep sea show reworking by benthonic animals, usually described as "burrow mottling" in core descriptions. This sediment mixing, or bioturbation, obliterates primary sedimentary structures and gives rise to bioturbate texture; when intense, it results in complete homogenization of the sediments. Photos of the sea bed in all depths commonly show evidence of animal activities such as trails, holes, and mounds; thus it is predictable that vertical profiles of sedimentary cores also exhibit biogenic structures that record a history of biological activity at the core site.

The biogenic sedimentary structures preserved in JOIDES and other deep-sea cores have received little attention to date. Bioturbation has been figured and noted in several papers (e.g., Pimm, et al., 1971), but most

\footnotetext{
${ }^{1}$ Present address: Department of Marine Sciences, University of Puerto Rico, Mayaguez, Puerto Rico.
}

discussions are brief (e.g., Seilacher, 1967, 424; Donahue, 1971) or incomplete. Surface trails have been studied by Bourne and Heezen (1965), Heezen (1970), and Heezen and Hollister (1971).

Current interest by paleontologists and sedimentologists in trace fossils of land-based exposures has resulted in recent significant publications and syntheses (Seilacher, 1964, 1967; Crimes and Harper, 1970; Osgood, 1970; Perkins, 1971). Papers on burrowing in deep sea sediments or on the consequences of burrowing and mixing for microfossil zonation, textural analyses, depositional rate determinations, etc., include Clarke (1968), Berger and Heath (1968), Piper and Marshall (1969), Hanor and Marshall (1971), and Donahue (1971).

\section{SAMPLES STUDIED}

This report is based largely on photographs of vertical sections of the cores. Identifications and descriptions were supplemented with 33 samples of original material in the form of quarter sections of cores, varying from 4 to $35 \mathrm{~cm}$ in length.

In general, bioturbation is intense, as evidenced by disrupted bedding, irregular laminations and lenses, and by the distinctive trace fossils described below. As inspection of the photo record of the cores shows (see elsewhere in this volume), the traces are most distinct near color or texture boundaries, as where clay and ash layers are interbedded with marl and chalk. Sediment is displaced both upward and downward across these boundaries.

Preliminary thin section observations show that smallscale structuring of the sediment, such as orientation of foraminiferal tests around burrow peripheries, was accomplished by the burrowers. We have not studied these small-scale features in detail.

Sediment in these cores superficially differs very little from Cretaceous chalks figured by Kennedy $(1967,1970)$, Frey (1970), Schneidermann (1970) and Hattin (1971). Such differences as exist are discussed below, after the description of the trace fossils.

\section{SYSTEMATIC DESCRIPTIONS}

Systematic descriptions of trace fossils generally follow the rules of the International Commission on Zoological Nomenclature, although taxa are not recognized formally as valid at this time. The prefix Ichno- identifies taxa as trace fossils rather than as remains of skeletal or other body parts.

The four most readily identifiable forms-Chondrites, Planolites, Teichichnus, and Zoophycos-are described. 
They are all long-ranging forms and are well known in rocks from widespread localities.

Ichnogenus CHONDRITES Sternberg 1833

Chondrites sp.

(Figure 1(A) and Plate 1)

Description: Figure 1(A) shows the classic reconstruction of Chondrites by Simpson (1957). It can be readily envisaged how our sections relate to the three-dimensional form, which is characterized as follows:

A system of branched horizontal burrows which rise toward a vertical centrum. The branches are arranged as regularly ramifying tunnels, which neither cross each other nor anastomose. The tunnels are circular in cross-section (unless modified by compaction), unlined, and of constant diameter within specimens. The tunnels may show a number of orders of branching, tend to be pinnate, and are always lateral and never equal. Symmetry, other than a radial tendency, is absent.

Discussion: Chondrites is represented widely in the cores. The most complete specimen found is exposed in a median vertical section through a burrow system, and is filled by dark sediment in a light chalky matrix (Plate 1, Figures A-C). Tube diameter is relatively constant ( $2 \mathrm{~mm}$ ), and there is clearly a network of horizontal tunnels diverging from a central vertical axial region. Some of the burrows are elliptical in cross-section (due to compaction), and all appear to be unlined. Other sections show the predominantly horizontal elements of the system (Plate 1).

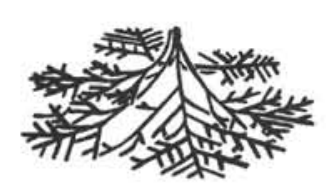

A

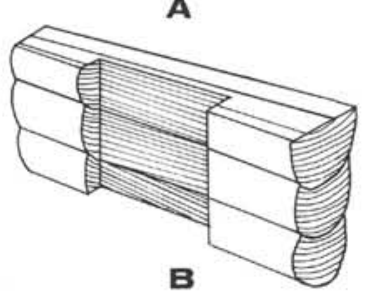

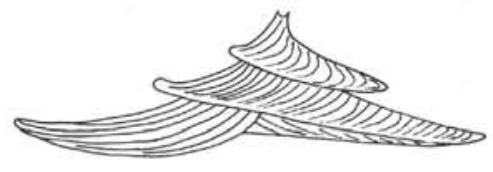

C
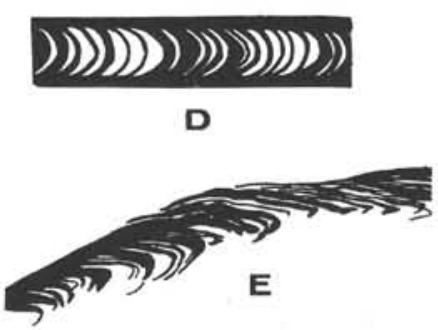

Figure 1. (A) Diagram of an idealized Chondrites (modified from Simpson, 1957, p. 484). Compare with core sections in Plate 1; (B) Diagram of an idealized Teichichnus, showing one possible arrangement of internal structure (redrawn from several sources). Compare with core sections in Plate 3; (C) Diagram depicting three-dimensional geometry of Zoophycos (modified from Hantzschel, 1962, p. w219). Compare with core sections in Plates 4 and 5; (D) Diagrammatic vertical cross-section of Zoophycos showing undisturbed dark matrix and curved laminations of reworked and sorted sediment (modified from Simpson, 1970, 1970, p. 509); (E) Section of part of Zoophycos specimen from site 146, 537 meters depth, Maestrichtian; height of trace 3-4 $\mathrm{mm}$.
Chondrites clearly represents the trace of a deposit feeding, vermiform organism, and is presently of unknown affinities.

Comparison with other occurrences: Chondrites is a cosmopolitan trace fossil, known from Cambrian to Tertiary marine sediments of all types. Ichnospecies are separated chiefly according to the details of branching pattern and size; species designation of the present material was not attempted.

Closest comparisons are with 1 to $2 \mathrm{~mm}$ diameter Chondrites described from European and North American chalks (Kennedy, 1967, 1970; Frey, 1970) and similar occurrences in Jurassic limestone-marl sequences where identical systems occur (Hallam, 1960; Sellwood, 1970).

The reworking of larger burrow fillings by the Chondrites animal can be matched exactly in European chalks (Kennedy, 1967, p. 149, pl. 2, fig. 4). Presumably reworked sediment is potentially richer in nutrients, better oxygenated, and/or more readily perforated by the Chondrites animal. Other examples of this association are noted by Seilacher (1964, p. 302, text-fig. 3) and figured by Saporta (1884).

See Table 1 for selected occurrences of Chondrites.

TABLE 1

Typical Occurrences of Chondrite in Leg 15 Cores

\begin{tabular}{ccc}
\hline & $\begin{array}{c}\text { Depth } \\
\text { (nearest m) }\end{array}$ & \multicolumn{1}{c}{ Age } \\
\hline 146 & 478 & Maestrichtian \\
146 & 479 & Maestrichtian \\
146 & 479 & Maestrichtian \\
146 & 495 & Maestrichtian \\
146 & 518 & Maestrichtian \\
146 & 519 & Maestrichtian \\
146 & 519 & Maestrichtian \\
146 & 529 & Maestrichtian \\
146 & 537 & Maestrichtian \\
146 & 538 & Maestrichtian \\
146 & 539 & Maestrichtian \\
146 & 540 & Maestrichtian \\
146 & 545 & Maestrichtian \\
153 & 405 & Early Miocene \\
153 & 406 & Early Miocene \\
153 & 406 & Early Miocene \\
153 & 409 & Early Miocene \\
153 & 409 & Early Miocene \\
\hline
\end{tabular}

Ichnogenus PLANOLITES Nicholson 1873

Planolites sp.

(Plate 2)

Description: Most cores show varying degrees of mottling by vertical, horizontal, and inclined cylindrical burrows, varying from 5 to $12 \mathrm{~mm}$ in diameter (Plate 2). Usually simple, straight, or curved, these structures occasionally branch and generally maintain a uniform diameter.

Discussion and comparison with other occurrences: Planolites lack distinctive features. These specimens can be matched most satisfactorily with traces figured by Frey (1970) from the Santonian Fort Hayes Limestone of the Niobrara chalks of Kansas and described as "irregular, horizontal or inclined burrows, generally about $1 \mathrm{~cm}$ in 
diameter, filled by sediment passing through the vermiform organism's alimentary canal; burrows meander and undulate more or less randomly, and may branch" (p. 16). There is also a close resemblance to some of the bioturbation levels in European chalks (Kennedy, 1970, pl. 1, fig. 1).

This ichnogenus occurs in Precambrian to late Mesozoic sediments. Some Planolites are filled with subsequent Chondrites traces (see Plate 2).

TABLE 2

\begin{tabular}{ccc}
\multicolumn{3}{c}{ Typical Occurrences of Planolites } \\
in Leg 15 Cores
\end{tabular}

Ichnogenus TEICHICHNUS Seilacher 1955

Teichichnus sp.

(Figure 1(B) and Plate 3)

Description: Teichichnus is a wall-like, internally laminated trace produced by the vertical migration of horizontal cylindrical burrows. Figure $1(B)$ is a diagrammatic reconstruction of the three-dimensional form. The Caribbean cores show numerous sections of vertical or steeply inclined trough-like structures up to $2 \mathrm{~cm}$ wide and $5 \mathrm{~cm}$ high, with internal thin, hemicylindrical, concave-upward laminae which are horizontal or slightly inclined. The sides of these structures are parallel sided in some cases; others are irregular or distorted.

Discussion: In most of the Caribbean examples it is difficult to be certain of the three-dimensional form of the spreite represented, or even to be certain that these are not sections subparallel to the surface of Zoophycos (see below). However, two specimens are clearly elongate and certainly can be designated as Teichichnus; one specimen is figured on Plate 3, Figures A-C. It is very likely that all examples in Plate 3 represent sections cut through Teichichnus traces.

Structures of this type can be produced as a result of disturbance and redistribution of sediment by displacement of the burrow system, leaving a reworked filling, floor or spreite. Some modern arthropods and other organisms backfill their burrows, leaving a cylindrical, plugged tube, sections of which are comparable to forms in these cores (Kennedy and MacDougall, 1969; Chisholm, 1970a). Floor deposits of arthropod burrows are also superficially similar and are produced by the redistribution of sediment dislodged from the burrow roof (Shinn, 1968; Kennedy,
1970). Upward (retrusive) or downward (protrusive) migration of $U$ burrows in response to sedimentation and erosion also gives a reworked septum of similar appearance in section (Goldring, 1962; Sellwood, 1970). These appear to be feeding/dwelling burrows.

Comparison with other occurrences: Teichichnus-like burrows are widely known in sediments ranging from Cambrian to Tertiary in age, in marine siltstones, sandstones, calcarenites and chalks. Similar forms occur in European Cenomanian chalks. Closely comparable sections have been figured by Frey (1970) in Cretaceous chalks, Frey and Howard (1970) in Cretaceous chalks and clastics, and also in clastic sediments by Martinsson (1965) in the Cambrian and Chisholm (1970b) in the Carboniferous.

TABLE 3

Typical Occurrences of Teichichnus in Leg 15 Cores

\begin{tabular}{ccl}
\hline Site & $\begin{array}{c}\text { Depth } \\
\text { (nearest m) }\end{array}$ & \multicolumn{1}{c}{ Age } \\
\hline 146 & 495 & Maestrichtian \\
146 & 529 & Maestrichtian \\
146 & 537 & Maestrichtian \\
146 & 537 & Maestrichtian \\
146 & 539 & Maestrichtian \\
146 & 540 & Maestrichtian \\
146 & 549 & Maestrichtian \\
146 & 550 & Maestrichtian \\
146 & 551 & Maestrichtian \\
146 & 613 & Campanian \\
146 & 621 & Campanian \\
152 & 417 & Campanian \\
153 & 669 & Santonian \\
\hline
\end{tabular}

\section{Ichnogenus ZOOPHYCOS Massalongo 1855}

Zoophycos sp.

(Figure 1(C-E) and Plates 4, 5)

Description: Zoophycos from the Caribbean cores can be matched with material figured by many workers. A complete specimen is a spiral, sheet-like structure similar to the reconstruction in Figure 1(C), and clearly shown in the specimen on Plate 5, Figures D-E. The spiral is of low pitch, with considerable variation in the amount of lateral expansion in succeeding whorls downward (Plates 4 and 5). Sections through the sheet itself show the numerous parallel lamellae that are gently curved in plane, and generally $\mathrm{C}$-shaped in vertical transverse section (Figure 1 [D and E]). The latter are expressed as the characteristic alternating dark and light lunae, (Figure 1 [D and E]; Plates 4 and 5).

In the vertical core sections, Zoophycos appears as ribbons 1 to $4 \mathrm{~mm}$ thick, extending laterally across the core faces and undoubtedly for several decimeters when complete in situ. They commonly run horizontally or at low angles across the core sections, arranged in parallel, subparallel or slightly diverging groups of two to several ribbons 6 to $40 \mathrm{~mm}$ apart; perhaps some Zoophycos ribbons one or more decimeters apart belong to the same large specimen, but this is not clear from the limited exposure and geometry on the core faces. 
Discussion: According to the work of Simpson (1970) and others, these lamellae represent alternations of collapsed burrow and undisturbed sediment produced by repeated, closely spaced grazing movements of the cylindrical, vermiform feeding apparatus of some unknown animal. The whole burrow system is thus a reworked sheet of sediment-a spreite.

In our view, these structures are without doubt tracefossils; they clearly cut preexisting burrow structures and show internal morphology incompatible with some currently held views that they are algae (Loring and Wang, 1971) or sabellid prostomia (Plička, 1970).

The Caribbean cores show many biogenic structures that have the Zoophycos geometry of being horizontal or inclined and of constant width, resembling this taxon in every respect except that the discrete lunae within the reworked zones are absent or only vaguely expressed. The exact differences in color and/or texture between the lunae and matrix have not been studied in our samples.

Comparison with other occurrences: Zoophycos is a cosmopolitan trace-fossil which ranges from Ordovician to Recent and occurs in lithologies which include clays, chalks, fine-grained sandstones and even vitric tuffs (see Taylor, 1967, for discussion and extensive review of occurrences).

Descriptions and figures which can be matched most closely with our material include the Niobrara chalks of Kansas (Frey, 1970), the Banderkreide facies of the north-west European Upper Cretaceous (Voigt, 1929; Voigt and Hantzschel, 1956; Kennedy, 1970), the Fossil Bluff Series (Aptian) of Alexander Island, Antarctica (Taylor, 1967), and the Tertiary of New Zealand (Webby, 1969; Lewis, 1970).

Some occurrences of Zoophycos in the Caribbean cores are listed in Table 4.

TABLE 4

Typical Occurrences of Zoophycus in Leg 15 Cores

\begin{tabular}{ccl}
\hline & $\begin{array}{c}\text { Depth } \\
\text { Site }\end{array}$ & \multicolumn{1}{c}{ Age } \\
\hline 146 & 480 & Maestrichtian \\
146 & 480 & Maestrichtian \\
146 & 509 & Maestrichtian \\
146 & 520 & Maestrichtian \\
146 & 523 & Maestrichtian \\
146 & 528 & Maestrichtian \\
146 & 536 & Maestrichtian \\
146 & 537 & Maestrichtian \\
146 & 537 & Maestrichtian \\
146 & 538 & Maestrichtian \\
146 & 540 & Maestrichtian \\
146 & 545 & Maestrichtian \\
146 & 545 & Maestrichtian \\
146 & 550 & Maestrichtian \\
146 & 550 & Maestrichtian \\
146 & 621 & Campanian \\
146 & 622 & Campanian \\
153 & 413 & Miocene \\
153 & 733 & Santonian \\
\hline
\end{tabular}

\section{OTHER BURROWS}

Vertical sections of the cores show a variety of vermiform burrows which cannot be named with certainty (Plate 6); future study of the traces in three dimensions may show some of them to be comparable with forms described and named from elsewhere. The majority of these are burrows of deposit-feeding invertebrates. Some appear to have been lined (Plate 6, Figures A and B), and a few possibly were permanent or semipermanent dwelling burrows (Plate 6, Figures A-C). Plate 6, Figures E, G, shows a goblet-shaped structure that superficially resembles a variety of the trace fossil Asterosoma, a common Cretaceous burrow comprised of a vertical tube with a funnel-shaped opening (Frey, 1970). Inspection of the core shows that this structure is elongate, being a V-shaped trough over a vertical wall; the structure is recrystallized carbonate veins in a limestone matrix. In view of the suite of traces present in these cores it would not have been surprising to find Asterosoma, but this sample apparently is not of organic derivation. Plate $6 \mathrm{~F}$ shows a variety of burrows interrupted by a 4 to $6 \mathrm{~cm}$ interval of sweeping cross laminations. This interval is overlain by an irregular Teichichnus; the underlying laminations appear to be part of the trace of the same Teichichnus animal, which changed its direction of excavation. If these laminations represent primary sedimentary structures rather than trace fossils, they are the only such undisturbed structures in this part of the core.

TABLE 5

Selected Intervals Showing Well-Developed Burrows or Trace Fossils Other than the Specific Occurrences Noted Above

\begin{tabular}{ccl}
\hline Site & $\begin{array}{c}\text { Depth } \\
\text { (nearest m) }\end{array}$ & Age \\
\hline 146 & 478 & Maestrichtian \\
146 & 479 & Maestrichtian \\
146 & 501 & Maestrichtian \\
146 & 502 & Maestrichtian \\
146 & 507 & Maestrichtian \\
146 & 529 & Maestrichtian \\
146 & 535 & Maestrichtian \\
146 & 537 & Maestrichtian \\
146 & 539 & Maestrichtian \\
146 & 539 & Maestrichtian \\
146 & 540 & Maestrichtian \\
146 & 546 & Maestrichtian \\
146 & 549 & Maestrichtian \\
153 & 408 & Early Miocene \\
153 & 734 & Early Santonian \\
\hline
\end{tabular}

\section{PRESERVATION}

Most of the trace fossils in these cores are visible as dark markings against a light matrix. In certain intervals, however, the traces appear light against a dark background, such as the Zoophycos in Plate 4, Figures B and C, and Plate 5, Figure A. These differences in expression of the traces appear fortuitous within short distances in the cores. With depth, however, there is a general improvement in contrast, with increased age or overburden accentuating the traces in some way. Plate 5, Figure $\mathrm{F}$ shows two faint 
Zoophycos traces from poorly consolidated lower Miocene sediment at 412 meters, Site 153. Plate 5, Figure A is a Santonian Zoophycos from 733 meters at the same site, where the sediment is indurated and the traces much more distinct. A general lack of trace fossils from conventional short cores may owe to the fact that the structures have not been accentuated by geochemical processes during diagenesis and lithification.

\section{DISCUSSION AND INTERPRETATION}

Abundant occurrences of the most distinctive trace fossils in the cores (Chondrites, Teichichnus and Zoophy$\cos$ ) through hundreds of meters of sediment indicate that the animals responsible for the traces existed for millions of years in a deep marine environment. Presence of the trace fossils, as well as the intense bioturbation exhibited in the cores, requires that the bottom waters be oxygenated when the traces were formed, and that the sediment contained enough organic detritus or other food to support a diversity of deposit-feeding animals. Most marine environments fulfill these prerequisites.

\section{Identification of Trace Fossil Animals}

A perpetual problem with trace fossils is that they represent the behavior of organisms rather than actual body parts. Different species of animals can produce traces that are of exact or similar geometry and scale, and conversely the same or related animals can possess a variety of behavioral patterns giving rise to dissimilar structures. Zoophycos, for instance, shows many variations of a general feeding behavior (see references above). These variations may represent different species (closely or not closely related phylogenetically), each of which has different habitat requirements. If such is the case, the ichnogenus has little value for environmental interpretation unless the habitat specificity of the varieties can be documented.

A continuing disappointment for paleontologists is that deep-sea studies have not yielded the identities of the animals producing such long-lived and distinctive traces as Chondrites and Zoophycos. Either the animals have recently become extinct, have not been sampled, or are not recognized as the fabricators of these traces. The latter possibility seems most likely to us.

\section{Paleobathymetric Interpretations}

The entire assemblage of trace fossils from the Caribbean fits the environment of deposition postulated for the sediments. Deep, quiet water with fine-grained sediments favors deposit-feeding animals that have developed systematic methods for exploiting the sediment for food, and which thus gave rise to these distinctive structures. It is recognized that Chondrites and Planolites have little value as bathymetric indicators, being cosmopolitan and crossing both bathymetric and lithologic facies boundaries (Häntzschel, 1962; Seilacher, 1964). Teichichnus and Zoophycos commonly occur together in what could be regarded as quiet water environments. They may have lived in water as shallow as 100 meters or less judging from their cooccurrence off reef flanks in Mississippian rocks of southeastern
New Mexico. Zoophycos occurs abundantly in almost certainly shallow-water cyclic limestones in Pennsylvanian rocks of central Texas (Warme and Olson, 1971), and in shallow-water sediments elsewhere (Osgood and Szmuc, 1972).

Comparison of this trace fossil assemblage with ichnofaunas described from land-based localities confirms that similar sedimentary regimes yield similar assemblages or ichnofaunas. Furthermore, it suggests that most ichnogenera respond to sedimentary regime rather than absolute depth.

Two suites of trace fossils similar to those in the Caribbean cores are described by Seilacher (1963) and Taylor (1967). The latter assemblage is Cretaceous (Aptian) from Alexander Island, Antartica and contains Zoophycos, Chondrites, and Planolites in a thick sequence of volcanicrich sediments.

Seilacher (1963) outlined three ichnofacies from an Ordovician geosynclinal sequence in Iraq, where a correspondence between sediment types, sedimentary structures, and trace fossils indicated three paleobathymetric zones. A Cruziana facies represented conditions "above wave base"; a Nereites facies represented "deep geosynclinal conditions"; and a Zoophycos facies was intermediate between them. Typical of the latter facies is Chondrites, Teichichnus, and Zoophycos. Seilacher $(1964,1967)$ extended this scheme to include more ichnogenera from this and other geographic localities, and showed that many forms such as Chondrites are present in more than one ichnofacies. Seilacher's bathymetric scheme has been successfully applied by many workers (e.g., Rodriguez and Gutschick, 1970; Chamberlain, 1971a, 1971b).

The Caribbean assemblage exactly fits the Zoophycos facies, although it is probable that the absolute depth of the water was greater than either Seilacher's or Taylor's examples. Seilacher (1963) characterized this facies as "quiet water," whereas the deeper Nereites ichnofacies was a turbidite sequence. Displaced faunas at some horizons (Edgar, et al., 1971, p. 13), and thin graded beds and cross-laminations suggest that turbidites are present, although primary sedimentary structures of any kind are rare owing to the pervasive bioturbation.

Other land-based assemblages that are very similar to the Caribbean occurrences are in the thinner but widespread Mesozoic limestones of Europe and North America. These rocks are similar to the Caribbean cores in age and lithology, but differ because they were deposited in shallow water. Trace fossils in these sediments are described by Bromley (1967, 1968), Kennedy (1967, 1970), Kennedy and MacDougall (1969), Frey (1970), Frey and Howard (1970), and Hattin (1971), and Chrondrites, Planolites, Teichichnus, Zoophycos and other forms are well documented. A striking dissimilarity, however, is that the land-based rocks also contain Thalassinoides, a Triassic to modern form typical of shallow-water sediments. Thalassinoides usually occurs in abundance, is easily identified, and is widely used along with related forms as an indicator of shallow water (Weimer and Hoyt, 1964). Although there appears to be some disagreement as to the precise depth of 
deposition of some widespread Cretaceous limestones in Kansas and Colorado, whether they were deposited in 500 to 600 meters (Eicher, 1969) or 200 meters or less (Kauffman, 1967; Hattin, 1971), these depths are certainly less than that where the Caribbean chalks and marls accumulated (see elsewhere in this volume).

From the occurrences described above it is clear that the presence of single ichnogenera have little significance for paleobathymetric determinations; however, analysis using the entire ichnofacies assemblage, as well as lithofacies and biofacies criteria, will prove useful in paleoecological reconstructions.

\section{SUMMARY AND CONCLUSIONS}

1. Deep Sea Drilling Project Leg 15 cores from the Caribbean Sea exhibit an abundance and diversity of biogenic sedimentary structures.

2. These include intense burrow-mottling or bioturbation throughout the cores, and a spectacular assemblage of distinctive trace fossils in the more indurated chalks and marls in the lower parts of the cores. The trace fossils have been recognized only rarely in deep-sea cores.

3 . Four readily identifiable ichnogenera that are common in the cores (Chondrites, Planolites, Teichichnus, and Zoophycos) were originally described from land-based sections of sedimentary rocks; some are found in rocks as old as late Precambrian, and all occur over widespread geographic areas.

4. The trace fossil assemblage is most similar to quietand deep-water assemblages described from land-based exposures, most notably with the Zoophycos ichnofacies from Ordovician rocks in Iraq (Seilacher, 1963).

5. The assemblage is also similar to that in shallow-water Cretaceous chalks and Jurassic and Cretaceous limestones of Europe and North America, except for the absence of the common shallow-water form Thalassinoides.

6. Assemblages of trace fossils, in concert with other paleontological and stratigraphical data, are useful for paleonenvironmental reconstructions.

\section{REFERENCES}

Berger, W. H. and Heath, G. R., 1968. Vertical mixing in pelagic sediments. J. Marine Res. 26, 134.

Bourne, D. W. and Heezen, B. C., 1965. A wandering Enteropneust from the abyssal Pacific and the distribution of "spiral" tracks on the sea floor. Science. 150, 60.

Bromley, R. G., 1967. Some observations on burrows of thalassinidean crustaceans in chalk hardgrounds. Quart. J. Geol. Soc. London. 123, 157.

1968. Burrows and borings in chalk hardgrounds. Medd. Dansk. Geol. Foren. 18, 247.

Chamberlain, C. K., 1971a. Bathymetry and paleoecology of Ouachita Geosyncline of southeastern Oklahoma as determined from trace fossils. Bull. Am. Assoc. Petrol. Geologist. 55, 34 . 1971 b. Morphology and ethology of trace fossils from Ouachita Mountains, southeast Oklahoma. J. Paleont. 45, 212.

Chisholm, J. I., 1970a. Lower Carboniferous trace-fossils from the geological survey boreholes in West Fife (1965-1966). Bull. Geol. Surv. G. B. 31, 19. 1970b. Teichichnus and related trace-fossils in the Lower Carboniferous at St. Monance, Scotland. Bull. Geol. Surv. G. B. 32, 21 .

Clarke, R. H., 1968. Burrow frequency in abyssal sediments. Deep-Sea Res. 15, 397.

Crimes, T. P. and Harper, J. C., (Eds.), 1970. Trace Fossils. Liverpool (Seel House Press), 547.

Donahue, J., 1971. Burrow morphologies in north-central Pacific sediments. Marine Geol. 11, M1.

Edgar, N. T., et al., 1971. Deep sea drilling project Leg 15. Geotimes. 16, 12.

Eicher, D. L., 1969. Paleobathymetry of Cretaceous Greenhorn sea in eastern Colorado. Bull. Am. Assoc. Petrol. Geologists. 53, 1075.

Frey, R. W., 1970. Trace-fossils of Fort Hayes Limestone Member of Niobrara Chalk (Upper Cretaceous) westcentral Kansas. Paleont. Contrib. Univ. Kansas, Article 53.

Frey, R. W. and Howard, J. D., 1970. Comparison of Upper Cretaceous ichnofaunas from siliceous sandstones and chalk, Western Interior Region, U. S. A. J. In Trace Fossils. T. P. Crimes and J. C. Harper (Eds.). Liverpool (Seel House), 547 p. 141.

Goldring, R., 1962. The trace-fossils of the Baggy Beds (Upper Devonian) of North Devon, England. Palaont. Z. 36, 232.

Hallam, A., 1960. A sedimentary and faunal study of the Blue Lias of Dorset and Glamargan. Phil. Trans. Royal Soc. London. 243B, 1.

Hanor, J. S. and Marshall, N. F., 1971. Mixing of sediment by organisms. In Trace Fossils (Guidebook). B. F. Perkins (Ed.). Baton Rouge, Louisiana (Louisiana State University). 127.

Häntzschel, W., 1962. Trace fossils and problematica. In Moore, R. C. (Ed.). Treatise Invertibrate Paleontology. Part W, Miscellanea. Lawrence, Kansas (University Kansas Press). 259 p. W177.

Hattin, D. E., 1971. Widespread, synchronously deposited, burrow-mottled limestone beds in Greenhorn Limestone (Upper Cretaceous) of Kansas and southwestern Colorado. Bull. Am. Assoc. Petrol. Geologists. 55, 412.

Heezen, B. C., 1970. Modern abyssal ichnology. Geol. Soc. Am., Ann. Meeting, Milwaukee, (Abstr). 1970. 574.

Heezen, B. C. and Hollister, C. D., 1971. The face of the deep. London (Oxford). 659 p.

Kauffman, E. G., 1967. Coloradoan macroinvertebrate assemblages, central Western Interior United States. In Paleoenvironments of the Cretaceous seaway-a symposium. Colorado School of Mines, Golden, Colorado. 67.

Kennedy, W. J., 1967. Burrows and surface traces from the Lower Chalk of Southern England. Bull Br. Mus. Nat. Hist. Geol. 15, 127.

1970. Trace-fossils in the chalk environment. J. Geol. (Special Issue 3). In Trace Fossils. T. P. Crimes and J. C. Harper (Eds.). Liverpool (Seel House) 547 p. 263.

Kennedy, W. J. and MacDougall, J. D. S., 1969. Crustacean burrows in Weald Clay (Lower Cretaceous) of southeastern England and their environmental significance. Palaeontology. 12, 459.

Lewis, D. W., 1970. The New Zealand Zoophycos. New Zealand J. Geol. Geophys. 13, 295.

Loring, A. P. and Wang, K. K., 1971. Re-evaluation of some Devonian Lebensspuren. Bull. Geol. Soc. Am. 82, 1103.

Martinsson, A., 1965. Aspects of a Middle Cambrian thanatotope on Öland. Geol. För. Stockh. Förh. 87, 181. 
Osgood, R. G., 1970. Trace fossils of the Cincinnati area. Palaeontographica Americana. 41, 281.

Osgood, R. G. and Szmuc, E. J., 1972. The trace fossil Zoophycos as an indicator of water depth. Bull. Am. Paleont. 62, 5.

Perkins, B. F. (Ed.), 1971. Trace Fossils (Guidebook). Baton Rouge, Louisiana (Louisiana State University), $148 \mathrm{p}$.

Pimm, A. C., Garrison, R. E. and Boyce, R. E., 1971. Sedimentology synthesis: lithology, chemistry and physical properties of sediments in the northwestern Pacific Ocean. In Fischer, A. G., Heezen, B. C. et al., 1971, Initial Reports of the Deep Sea Drilling Project, Volume VI. Washington (U. S. Government Printing Office). 1131.

Piper, D. J. W. and Marshall, N. F., 1969. Bioturbation of Holocene sediments on La Jolla Deep Sea Fan, California. J. Sed. Pet. 39, 601.

Plička, M., 1970. Zoophycos and similar fossils. J. Geol. (Special Issue 3), In Trace Fossils. T. P. Crimes and J. C. Harper (Eds.). Liverpool (Seel House) 547 p. 301.

Rodriguez, J. and Gutschick, R. C., 1970. Late Devonian early Mississipian ichnofossils from western Montana and northern Utah. J. Geol. (Special Issue 3). In Trace Fossils. T. P. Crimes and J. C. Harper (Eds.). Liverpool (Seel House) 547 p. 407.

Saporta, G. de, 1884. Les organismes problématíques des anciennes mers. Paris.

Schneidermann, Nahum, 1970. Genesis of Cretaceous carbonates in Israel. Israel J. Earth-Sci. 19, 97.

Sellwood, B. W., 1970. The relation of trace-fossils to small-scale sedimentary cycles in the British Lias. J. Geol. (Special Issue 3). In Trace Fossils. T. P. Crimes and J. C. Harper (Eds.). Liverpool (Seel House) 547 p. 489.
Seilacher, A., 1963. Kaledonischer Unterbau der Irakiden. Neues Jb. Geol. u. Palaeont. Mh. 527.

1964. Biogenic sedimentary structures. In Approaches to Paleoecology. J. Imbrie and N. D. Newell (Eds.). New York (Wiley), 432 p. 296.

, 1967. Bathymetry of trace fossils. Marine Geol. 5 413.

Shinn, E. A., 1968. Burrowing in recent lime sediments of Florida and the Bahamas. J. Paleon. 42879.

Simpson, S., 1957. On the trace-fossil Chondrites. Quart. J. Geol. Soc. London. 112, 475.

1970. Notes on Zoophycos and Spirophyton. J. Geol. (Special Issue 3). In Trace Fossils. T. P. Crimes and J. C. Harper (Eds.). Liverpool (Seel House) 547 p. 505.

Taylor, B. J., 1967. Trace fossils from the fossil bluff series of Alexander Island. Bull. Brit. Antarctic Surv. 13, 1.

Voigt, E., 1929. Die Lithogense der Flach - und Tiefwasser sedemente des jungeren oberkreidemeres. Jb. Hall. Verb. 2. Erfarsch. d. Mitteldt. Bodenschätze. 8, 1.

Voigt, E. and Häntzschel, W., 1956. Die grauen Bänder in der Schreibkreie Nordwest-Deutschlands und ilrre Deutung als Lebensspuren. Mitt. Geol. Staatsinst. Hamburg. $25,104$.

Warme, J. E. and Olson, R. W., 1971. Stop 5: Lake Brownwood spillway. In Trace Fossils (Guidebook). B. F. Perkins (Ed.). Baton Rouge, Louisiana (Louisiana State University). 148 pp. 27.

Webby, B. D., 1969. Trace fossils Zoophycos and Chondrites from the Tertiary of New Zealand. New Zealand J. Geol. Geophys. 12, 208.

Weimer, R. J. and Hoyt, J. H., 1964. Burrows of Callianassa major Say, geologic indicators of littoral and shallow neritic environments. J. Paleont. 38, 761. 


\section{PLATE 1}

Examples of Chondrites. Bar scale equals two centimeters. Also see Figure 1(A). Specimens occur as radiating systems of burrows or as probings in or near older and larger burrows.

Figures A-C Almost perfect specimen showing axial centrum and radiating probes below.

A: Section exposed in archive half of core.

B: Two surfaces at 90 degree angle showing same specimen as (A), exposed in a quarter section of the core.

C: An enlargement of B.

Figures D-I Sections cut normal, oblique and transverse to burrows containing large and small Chondrites, and Chondrites systems that show no obvious geometry.

Figures J-K Chondrites specimen that appears inverted compared with specimen A-C.

$\mathrm{J}$ : Section exposed on archive half of core.

$\mathrm{K}$ : Two surfaces at 90 degree angle exposed on quarter section of core.

Site, Depth and Age of Specimens

\begin{tabular}{cccl}
\hline $\begin{array}{c}\text { Figure } \\
\text { (Specimen) }\end{array}$ & Site & $\begin{array}{c}\text { Depth } \\
\text { (nearest m) }\end{array}$ & Age \\
\hline A-C & 146 & 538 & Maestrichtian \\
D & 146 & 518 & Maestrichtian \\
E & 153 & 406 & Early Miocene \\
F & 146 & 496 & Maestrichtian \\
G & 146 & 540 & Maestrichtian \\
H & 153 & 409 & Early Miocene \\
I & 146 & 400 & Maestrichtian \\
J-K & 146 & 545 & Maestrichtian \\
\hline
\end{tabular}


PLATE 1
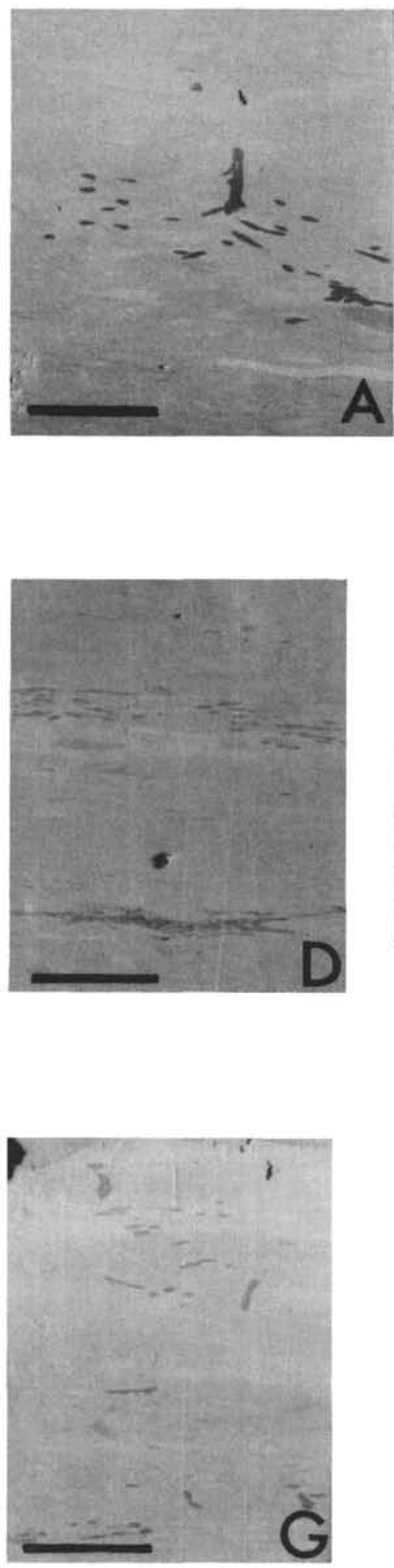
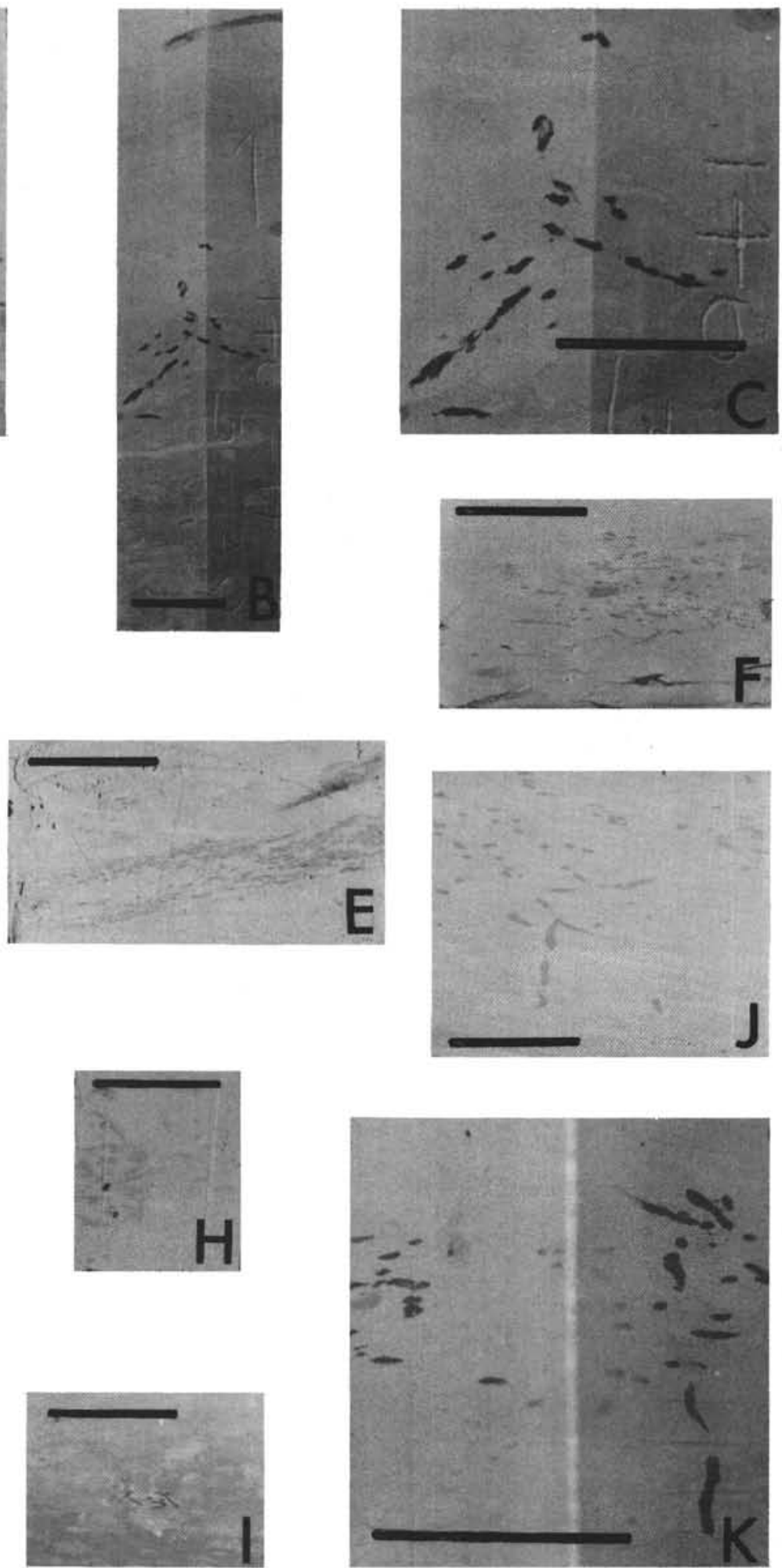


\section{PLATE 2}

Examples of Planolites. Bar scale equals 2 centimeters. Note multiple episodes of burrowing, with no readily apparent primary bedding remaining. Material on surface of $\mathrm{B}$ and $\mathrm{E}$ is mud from core-cutting operations.

Site, Depth and Age of Specimens

\begin{tabular}{cccl}
\hline $\begin{array}{c}\text { Figure } \\
\text { (Specimen) }\end{array}$ & Site & $\begin{array}{c}\text { Depth } \\
\text { (nearest m) }\end{array}$ & \multicolumn{1}{c}{ Age } \\
\hline A & 146 & 535 & Maestrichtian \\
B & 153 & 409 & Early Miocene \\
C & 146 & 530 & Maestrichtian \\
D & 146 & 537 & Maestrichtian \\
E & 146 & 501 & Maestrichtian \\
F & 153 & 405 & Early Miocene \\
\hline
\end{tabular}


PLATE 2
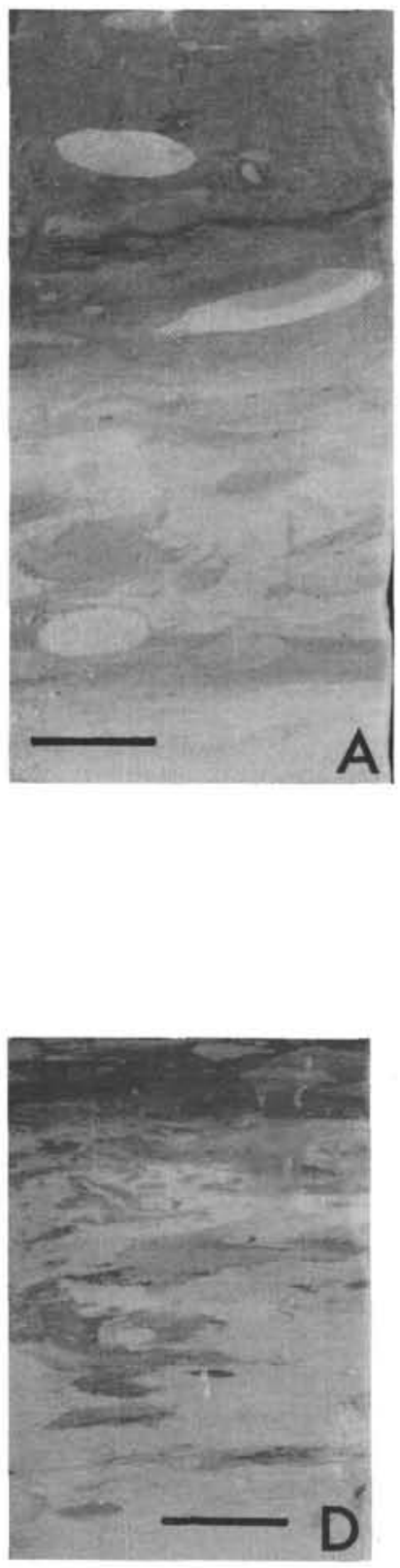
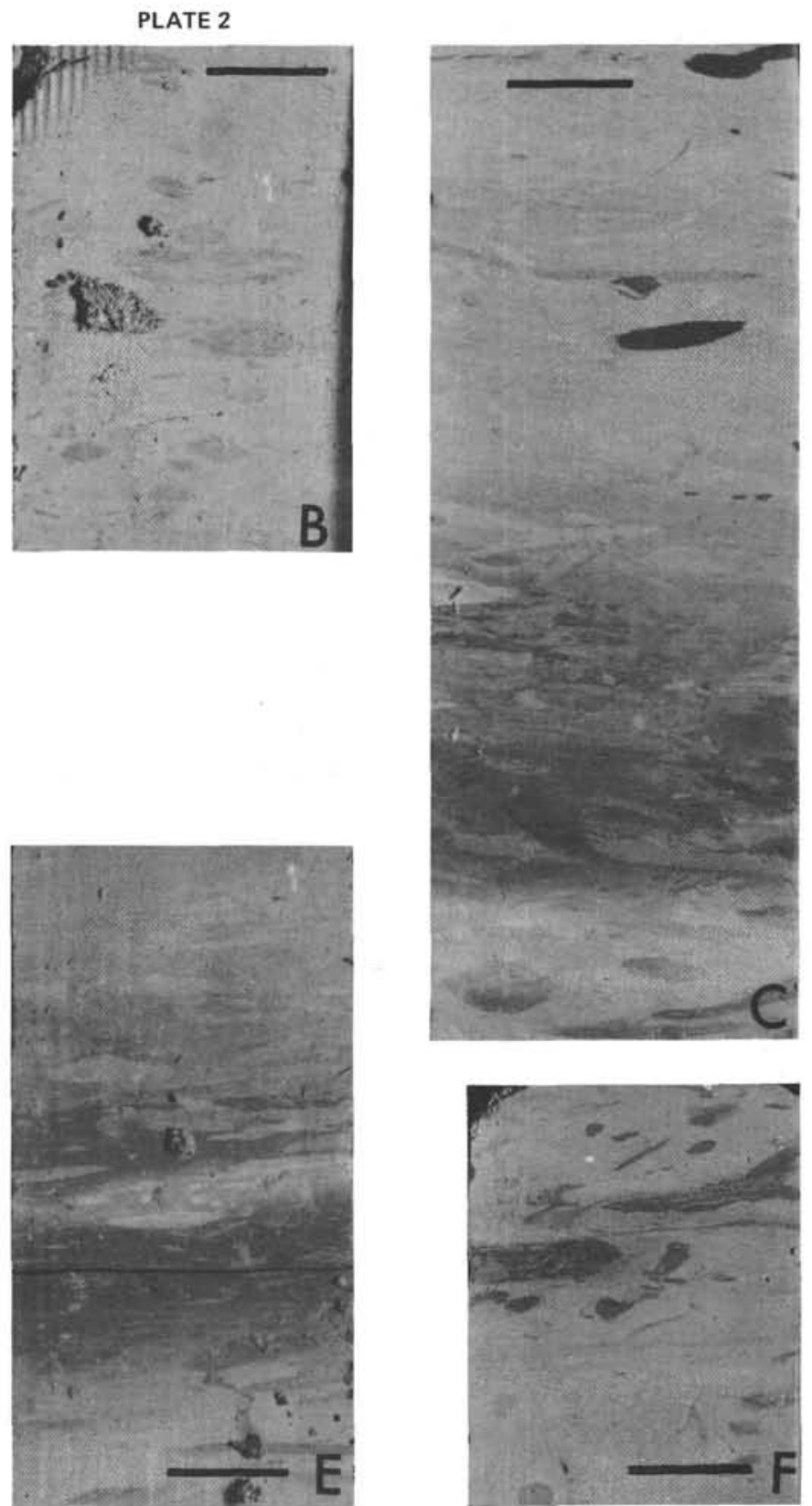


\section{PLATE 3}

Examples of Teichichnus. Bar scale equals 2 centimeters.

Figures A-C Teichichnus exposed on two surfaces of quarter section of core (B).

A: Laminae exposed along axis of specimen.

C: Same laminae as in A, showing curved surfaces exposed normal to long dimension of the trace. Compare with Figure 1(B).

Figures D, H Specimens of Teichichnus exposed on quarter section of core (D), and mirror image on archive half of core.

Figures E-G,I Specimens of Teichichnus that clearly show internal laminae in exposures approximately normal to longest dimension of the trace. Some are inclined $(E)$ or vertically irregular $(G)$, and may be distorted owing to compaction.

Figures $\mathbf{J}, \mathrm{K} \quad$ Two views of quarter section of core showing a Teichichnus-like trace in which the characteristic laminae are not well developed. Note other distinct and indistinct burrows crowding most core faces.

Site, Depth and Age of Specimens

\begin{tabular}{cccl}
\hline $\begin{array}{c}\text { Figure } \\
\text { (Specimen) }\end{array}$ & Site & $\begin{array}{c}\text { Depth } \\
\text { (nearest m) }\end{array}$ & \multicolumn{1}{c}{ Age } \\
\hline A-C & 152 & 418 & Campanian \\
D,H & 146 & 550 & Maestrichtian \\
E & 146 & 622 & Campanian \\
F & 146 & 615 & Campanian \\
G & 153 & 671 & Santonian \\
I & 146 & 551 & Maestrichtian \\
J,K & 146 & 529 & Maestrichtian \\
\hline
\end{tabular}


PLATE 3
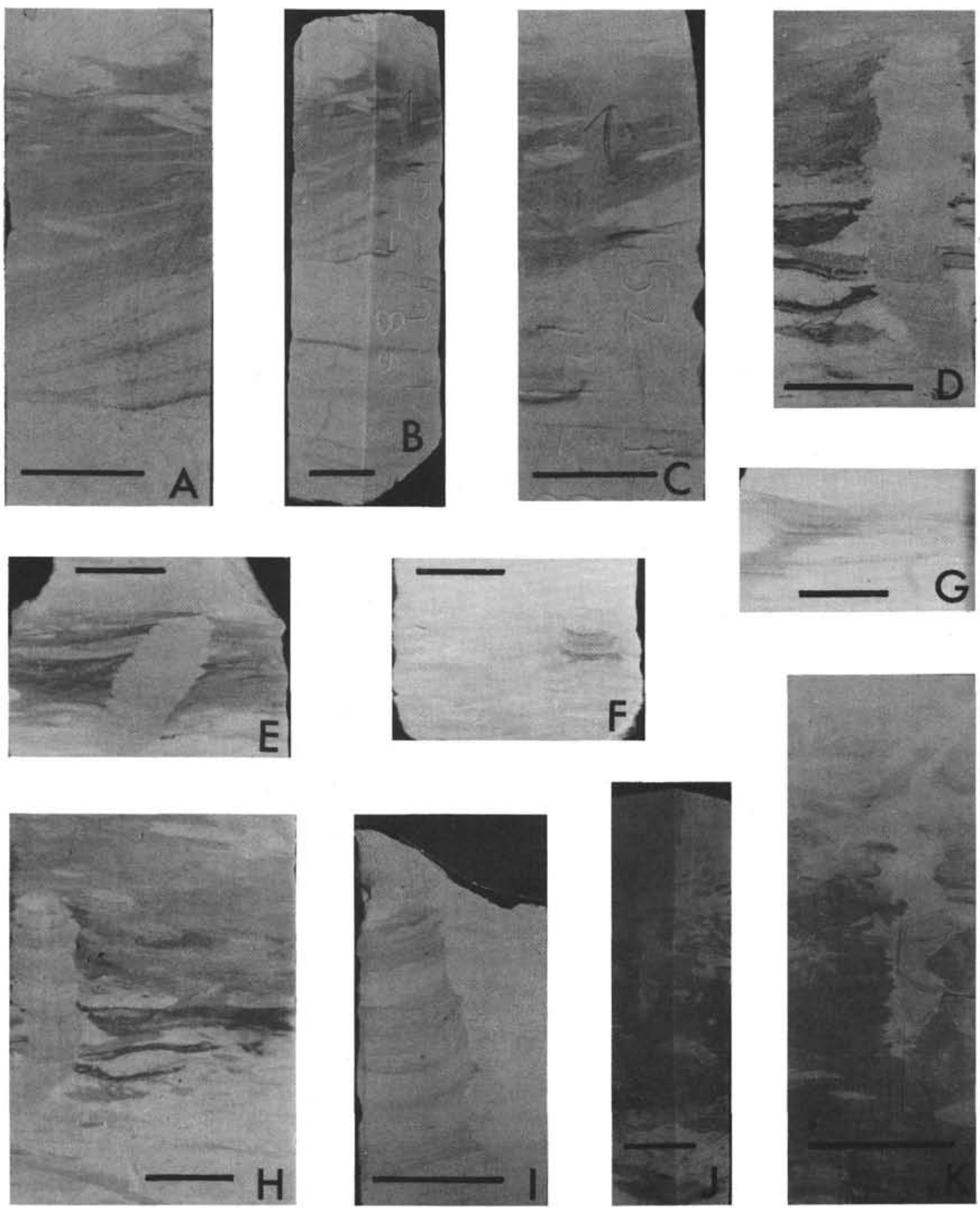


\section{PLATE 4}

Specimens of Zoophycos. Bar scale equals 2 centimeters.

Also see Plate 5.

Figure A Very well-preserved specimen showing dark, curved laminations of reworked sediment. See Figure 1(E) for outline drawing.

Figure B,C Stacked laminations of lighter sediment in a darker matrix, probably representing sections through small Zoophycos. Drawings to right suggest these are sections of spiral-shaped traces.

Site, Depth and Age of Specimens

\begin{tabular}{cccc}
\hline $\begin{array}{c}\text { Figure } \\
\text { (Specimen) }\end{array}$ & Site & $\begin{array}{c}\text { Depth } \\
\text { (nearest } \mathrm{m} \text { ) }\end{array}$ & Age \\
\hline A & 146 & 537 & Maestrichtian \\
$\mathrm{B}$ & 146 & 538 & Maestrichtian \\
$\mathrm{C}$ & 146 & 537 & Maestrichtian \\
\hline
\end{tabular}




\section{PLATE 4}
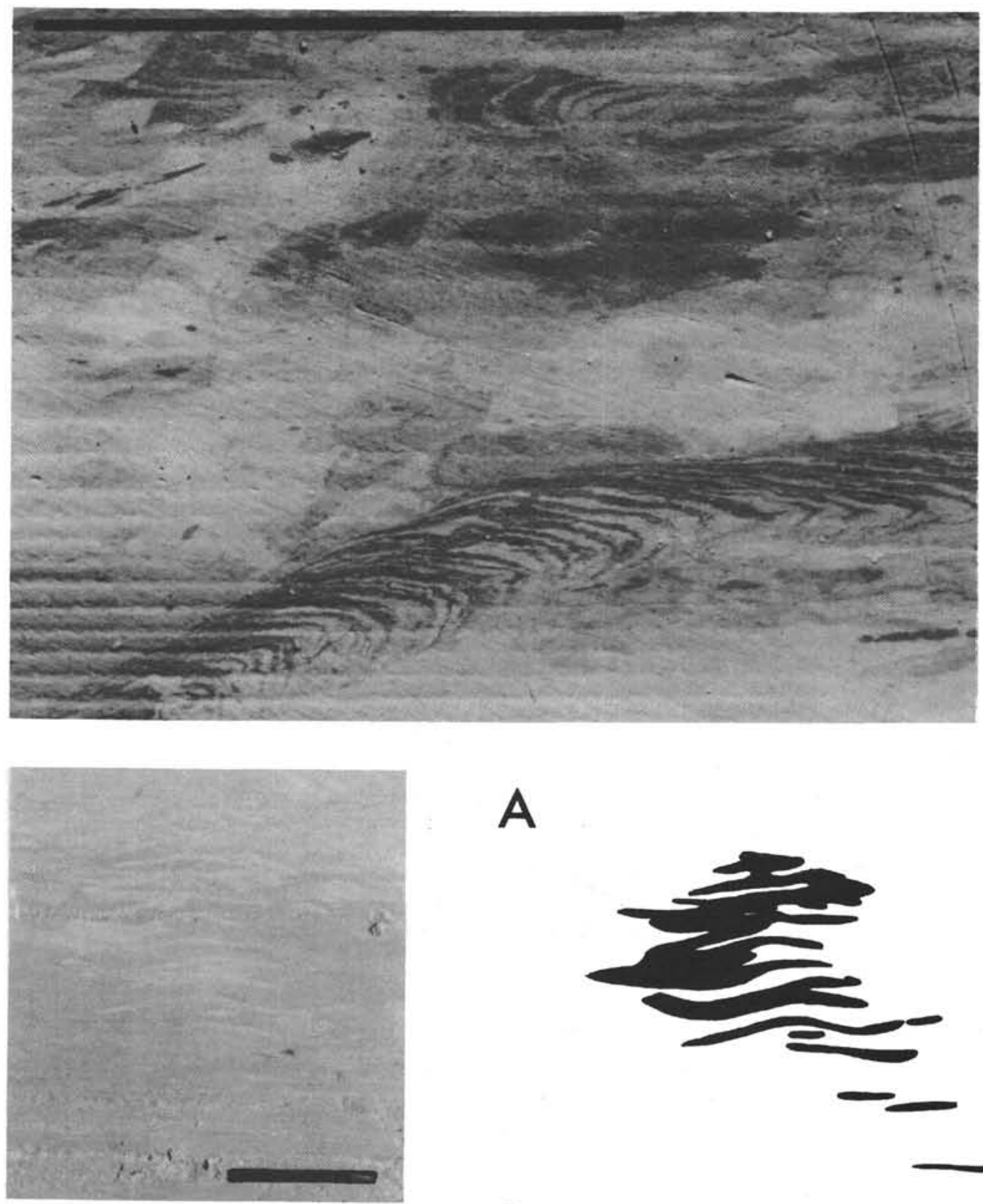

A

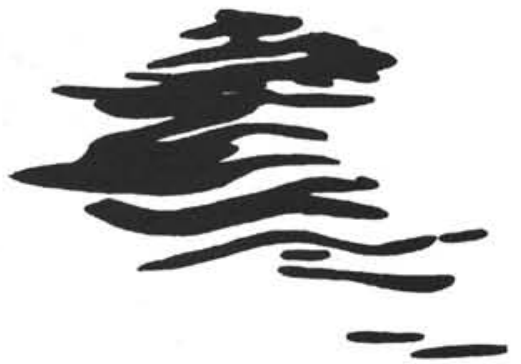

B

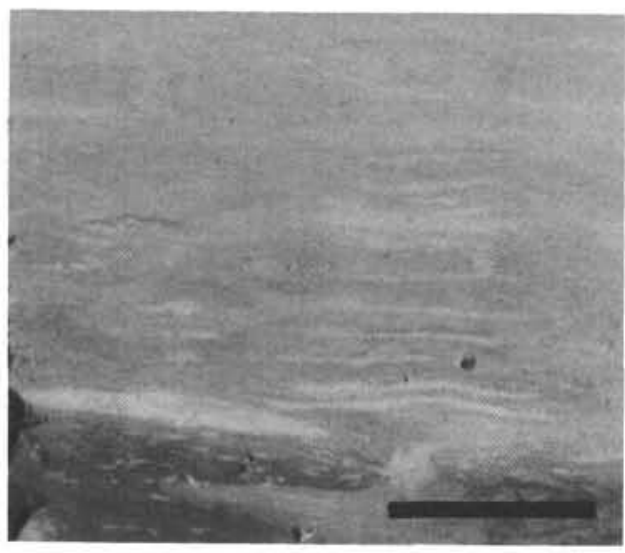




\section{PLATE 5}

Zoophycos showing sections of the spiral spriete system.

Bar scale represents 2 centimeters.

Figure A Two sections of sheets with characteristic internal laminations. Lower sheet has been disturbed by subsequent burrowers.

Figure B Five sheets arranged to suggest an expanding spiral of Zoophycos.

Figure C Similar to A, larger specimen.

Figure D,E Quarter section of core showing a complete Zoophycos in three dimensions.

Figure F Two diverging Zoophycos sheets, poorly accentuated in relatively unconsolidated Early Miocene sediment.

Figure G Three diverging sheets of Zoophycos, clearly crosscutting all other sedimentary structures. Note other traces in lower parts of the section.

Site, Depth and Age of Specimens

\begin{tabular}{cccl}
\hline $\begin{array}{c}\text { Figure } \\
\text { (Specimen) }\end{array}$ & Site & $\begin{array}{c}\text { Depth } \\
\text { (nearest m) }\end{array}$ & \multicolumn{1}{c}{ Age } \\
\hline A & 153 & 733 & Santonian \\
B & 146 & 540 & Maestrichtian \\
C & 146 & 536 & Maestrichtian \\
D,E & 146 & 501 & Maestrichtian \\
F & 153 & 412 & Early Miocene \\
G & 146 & 543 & Maestrichtian \\
\hline
\end{tabular}




\section{PLATE 5}
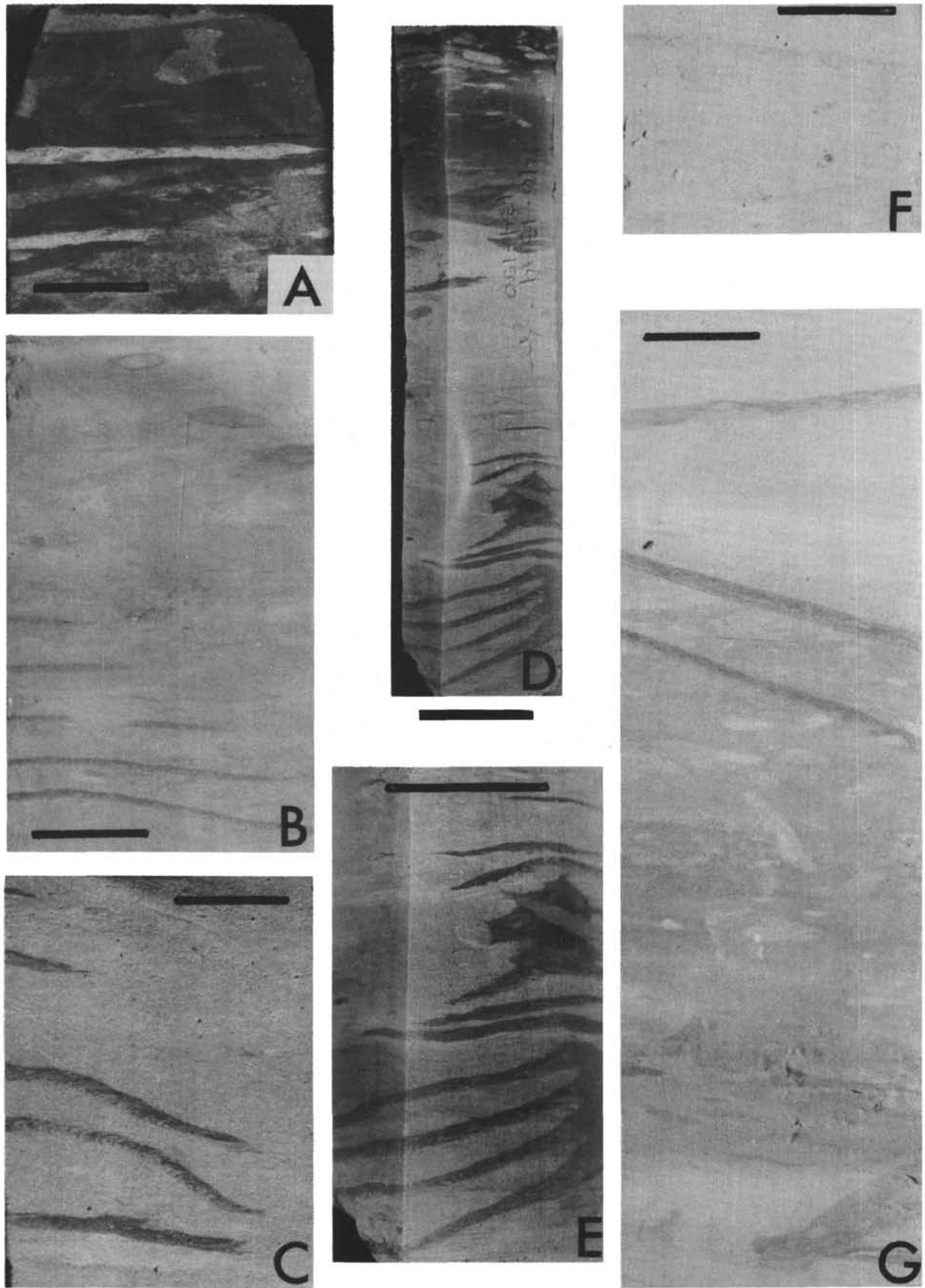


\section{PLATE 6}

Burrows and structures of special interest.

Bar scale equals 2 centimeters.

Figure A Vertical burrow, perhaps tube-shaped (below) and assorted burrows (above), all filled with Chondrites.

Figure B Irregular tube that appears to be lined with dark material.

Figure C Several burrows with dark linings. One at lower left appears to have four chambers, or alternatively four later probings, surrounded by darker linings.

Figure D Irregular, well-consolidated layers showing sediment lenses and disruption from burrowers that are accentuated by color contrasts.

Figure E-G Views of structure with geometry superficially similar to the ichnogenus Asterosoma, but comprised of carbonate vein fillings. The core interval is capped with chert. Figure E shows the face of the halved core; Figure F Irregular Teichichnus, see text; G is the same specimen intersecting the core periphery, demonstrating the elongate nature of the structure. Both geometry and mode of preservation of the specimen suggest this is not of organic genesis.

Site, Depth and Age of Specimens

\begin{tabular}{cccl}
\hline $\begin{array}{c}\text { Figure } \\
\text { (Specimen) }\end{array}$ & Site & $\begin{array}{c}\text { Depth } \\
\text { (nearest m) }\end{array}$ & \multicolumn{1}{c}{ Age } \\
\hline A & 153 & 408 & Early Miocene \\
B & 153 & 407 & Early Miocene \\
C & 146 & 528 & Maestrichtian \\
D & 153 & 735 & Santonian \\
E,G & 146 & 634 & Santonian \\
F & 146 & 539 & Maestrichtian \\
\hline
\end{tabular}



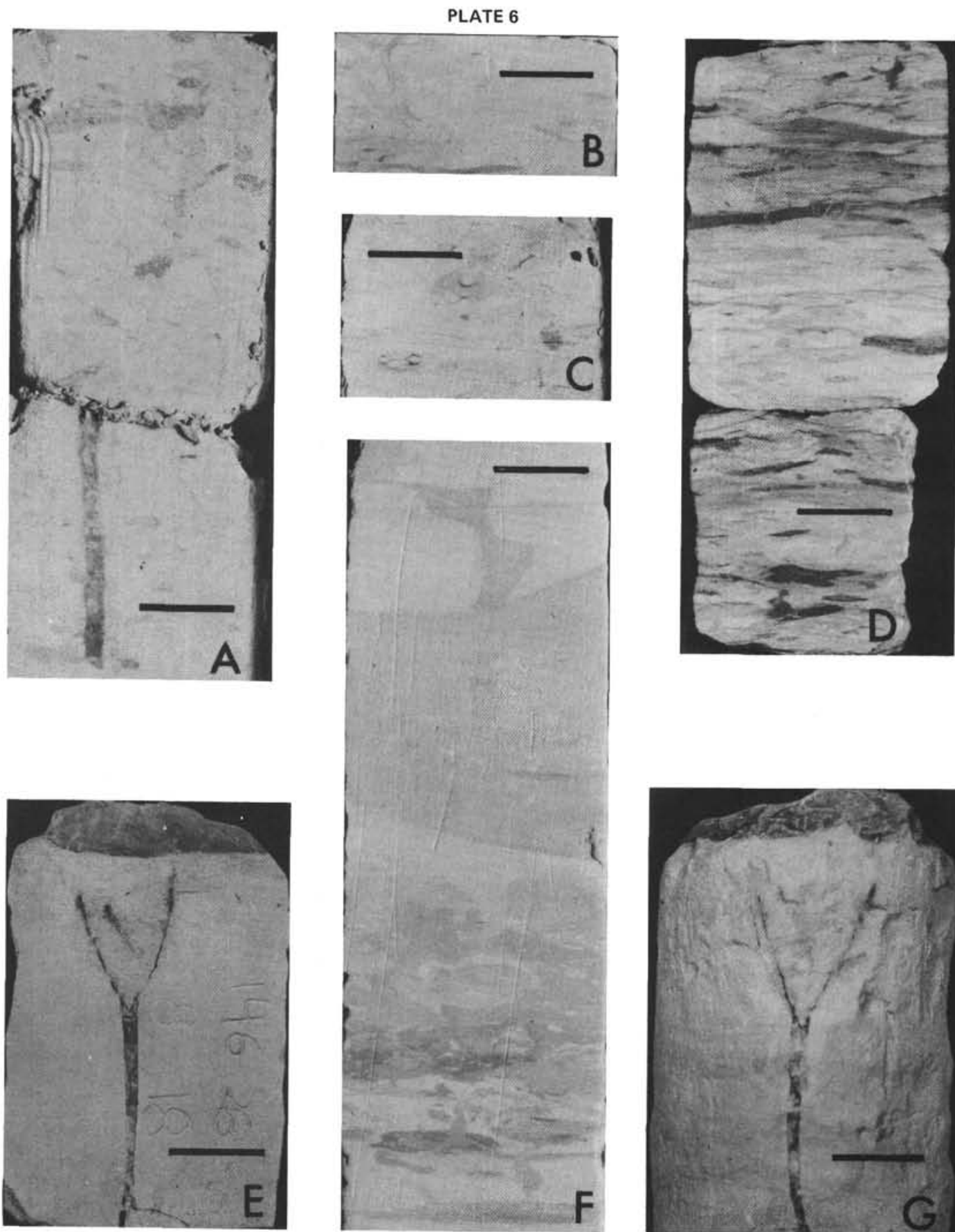